\title{
Pelatihan Pengenalan Aplikasi Pembelajaran Edmodo bagi Mahasiswa Universitas Kanjuruhan Malang
}

\author{
Siti Mafulah, Trisno Tunggal Rahayu Wilujeng \\ Universitas Kanjuruhan Malang, siti_mafulah@unikama.ac.id, trisonline@ymail.com
}

\begin{abstract}
In accordance with the vision of Universitas Kanjuruhan Malang as excellent campus in 2025 and excellent in education field in 2020, it is obviously important to do some actions. One of the ways is improving education quality through e-learning. The aims of this community service are 1) giving knowledge what kinds of application which can be applied in teaching learning process, 2) training the students in making Edmodo account, 3)knowing the students responses toward the use of Edmodo in teaching learning process. Method used in this activity is training. The steps were 1) introduced application that can be alternative media in teaching learning process, 2) introduced Edmodo as media, 3)workshop in making and joining group class, 4) simulation the use of Edmodo in small class and 5) evaluation. The finding of this activity was $85 \%$ students having good sense in applying Edmodo at class and Emodo is ready to be applied in class.
\end{abstract}

Keywords: training; media; edmodo

\begin{abstract}
Abstrak
Penggunaan e-learning dalam pembelajaran sangatlah dibutuhkan pada abad ini. Hal ini sesuai dengan visi universitas Kanjuruhan Malang, unggul pada tahun 2025 dan unggul dibidang pembelajaran pada tahun 2020 serta meningkatkan mutu pendidikan dengan e-learning maka sangat penting diadakan pelatihan yang mendukung visi ini. . Tujuan dari kegatan ini adalah: 1) memberikan pengetahuan tentang aplikasi apa yang dapat dipakai dalam pembelajaran 2) melatih mahasiwa universitas kanjuruhan malang tentang pembuatan akun Edmodo 3) mengetahui bagaimana tanggapan mahasiswa terkait pelatihan pembuatan akun edmodo. Metode yang dipakai dalam kegiatan ini adalah pelatihan dengan langkah-langkah sebagi berikut 1) memperkenalkan beberapa aplikasi yang dapat dipakai dalam kegiatan pembelajaran 2) pengenalan Edmodo sebagai media 3) pendampingan pembuatan akun dan join grup Edmodo 4) penerapan Edmodo dalam kelas kecil 5) evaluasi. Hasil yang didapatkan dari pelatihan ini adalah 85\% mahasiswa merespon bahwa pelatihan ini sangat mendukung pembelajaran dikelas. Bahkan mereka menyarankan untuk mengaplikasikan langsung aplikasi ini dalam pembelajaran mata kuliah Vocabulary.
\end{abstract}

Kata kunci: Pelatihan; Media; Edmodo 


\section{A. PENDAHULUAN}

Pendidikan tinggi di Indonesia haruslah siap menghadapi tantangan global yang sangat tinggi. Sudah menjadi tren jaman sekarang untuk bersaing secara sehat dalam dunia pendidikan. Seiring perkembangan teknologi, Universitas Kanjuruhan Malang mencetuskan visinya menjadi perguruan tinggi unggul pada tahun 2025. Pemanfaatan teknologi sebagai pendukung proses belajar mengajar sangatlah diperlukan. Minimnya penggunaan teknologi dalam proses pembelajaran di kalangan prodi pendidikan Bahasa Inggris membuat pengabdi tergugah untuk mangadakan pelatihan penggunaan suatu aplikasi sebagai media pembelajaran yang berbasis teknologi.

Masalah yang dihadapi oleh prodi dalam mencapai visi misi yang telah ditentukan adalah pertama minimnya dosen yang menggunakan teknologi dalam proses belajar pembelajaran dalam kelas. Sampai saat ini prosentasi pengampu mata kuliah dalam melaksasakan pengajaran berbasis teknologi masih sangat rendah, kurang dari 50\% saja. Kedua adalah minimnya pengetahuan mahasiswa dalam penggunaan teknologi sebagai penunjang keberhasilan pembelajaran dalam suatu mata kuliah menjadikan teknologi hanyalah alat hiburan semata. Hampir semua mahasiswa memiliki smartphone akan tetapi penggunaannya hanya sekedar untuk berkomunnikasi dan bersosialisasi dengan teman-teman yang lainnya saja. Ataupun hanya sekedar untuk menghibur diri dengan bermain youtube dan lain sebagainya yang tidak menunjang keberhasilan mereka dalam dunia pendidikan.

Berdasarkan masalah yang dimiliki mitra diatas, Solusi yang ditawarkan adalah pelatihan Edmodo bagi mahasiswa semester awal. Maka dari itu pelatihan pengenalan Edmodo diberikan pada mahasiswa semester dua. Berdasarkan hasil dari beberapa penelitian menunjukkan hasil yang bagus diantaranya: Asmuni dalam Mafulah (2017) menyatakan bahwa dalam penelitiannya Pengaruh Penggunaan Media Jejaring Sosial Edmodo terhadap Partisipasi Mahasiswa dalam Diskusi Kelas pada Materi Ajar Teoretis dan Praktis menyimpulkan bahwa hasil penelitiannya antara lain: pertama, terdapat pengaruh yang signifikan penggunaan media jejaring sosial Edmodo terhadap partisipasi mahasiswa dalam diskusi kelas pada materi ajar teoretis maupun praktis. Kedua terdapat hubungan yang signifikan antara penggunaan media jejaring sosial Edmodo dengan partisipasi mahasiswa dalam diskusi kelas pada materi ajar yang bersifat teoretis. Dan yang ketiga adalah adanya hubungan yang signifikan antara penggunaan media jejaring sosial Edmodo dengan partisipasi mahasiswa dalam diskusi kelas pada materi ajar yang bersifat praktis.

Kedua adalah penelitian yang dilakukan oleh Basori (2013) Penelitan yang dilakukan pada mata kuliah Teori Bodi Otomotif di Universitas Negeri Solo dengan menggunakan aplikasi Edmodo menyebutkan bahwa Terdapat peningkatan kualitas pengajaran dengan menggunakan Edmodo, yaitu menjadi kategori tinggi dan sangat tinggi. Hasil kedua yang diperoleh adalah Edmodo membantu menagement belajar mengajar dengan baik. Hasil ketiga yaitu penggunaan Edmodo dalam perkuliahan sangat mudah dan hasil keempat adalah tingginya angka kepuasan terhadap penggunaan edmodo sebagai media.

Target luaran yang diharapkan pada pelatihan ini adalah pertama, mahasiswa faham tentang apa itu media pembelajaran, manfaat media pembelajaran, peserta bisa mempraktekkan membuat akun dan Mahasiswa mampu mengaplikasikan Edmodo dalam kelas.

Berdasarkan fakta yang terjadi dan mengacu dari keberhasilan dari penelitian tersebut diatas maka sangat perlu dilakukan pelatihan penggunaan Edmodo pada 
mahasiswa prodi pendidikan bahasa Inggris Universitas Kanjuruhan Malang dengan tujuan meningkatkan kemampuan pemanfaatan teknologi dalam pembelajaran.

\section{B. PELAKSANAAN DAN METODE}

Kegiatan pengabdian ini menggunakan metode pelatihan. Pelatihan ini dilakukan di laboratorium bahasa, Fakultas Bahasa dan Sastra Universitas Kanjuruhan Malang pada tanggal 30 Maret 2017. Kegiatan ini dimulai dari pukul 07.30-12.00 WIB.

Pelatihan ini diikuti oleh peserta sebanyak 25 mahasiswa. Peserta pelatihan ini adalah mahasiswa Prodi Pendidikan Bahasa Inggris Universitas Kanjuruhan Malang yang berada pada semester dua tahun akademik 2017-2018 dan belum pernah menggunakan aplikasi Edmodo sama sekali.

Sedangkan langkah-langkah yang dilakukan dalam kegiatan ini adalah sebagai berikut:

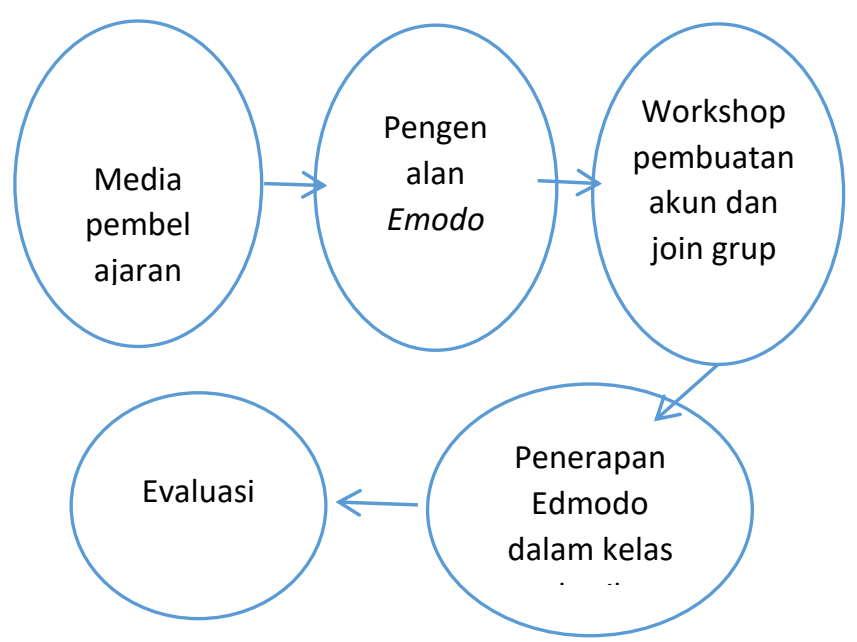

Bagan 1. Alur pelaksanaan kegiatan pengabdian

Seperti tergambar dalam bagan diatas metode yang dilakukan dalam kegiatan pengabdian ini antara lain :

Pertama pemberian pengetahuan dan wawasan tentang aplikasi yang dapat dimanfaatkan sebagai media dalam proses belajar mengajar di kelas. Pengenalan aplikasi pembelajaran ini dilalukan selama
60 menit. Dimulai dari pukul 08.00 hingga pukul 09.00 WIB.

Kedua pengenalan Edmodo sebagai media pembelajaran bahasa Inggris yang dapat diterapkan dalam kelas. Pada sesi ini di contohkan bagaimana pembuatan akun yang nantinya akan dapat dipergunakan untuk mengikuti kelas mata kuliah tertentu. Pengenalan Edmodo ini dipaparkan dalam kurun waktu 60 menit, dari pukul 09.0010.00 WIB.

Ketiga, workshop penggunaan aplikasi Edmodo dan penerapannya dalam pengajaran Bahasa Inggris pada kelas tertentu pada mata kuliah. Kegiatan keempat adalah penerapan edmodo dalam kelas kecil. Sesi ini dilaksanakan dalam 60 menit.

Sesi terakhir adalah evaluasi. Sesi ini dilakukan dengan memberikan kuisioner kepada peserta. Evaluasi diberikan dengan tujuan untuk mengetahui seberapa faham dan tertariknya mahasiswa dalam mengikuti pelatihan ini. Sesi ini diakhiri pada pukul 12.00 WIB

\section{HASIL DAN PEMBAHASAN}

Setelah langkah-langkah kegiatan dilaksanakan sesuai dengan apa yang telah direncanakan. Dari pengamatan yang telah dilakukan berikut pelaksanaan dari kegiatan pengabdian:

Sesi 1. Pendahuluan atau pembukaan

Pelaksanaan pelatihan ini dilakukan dengan regristasi peserta dan pembagian modul pelatihan. Kemudian dilanjutkan dengan pembacaan rangkaian acara yang dibawakan oleh pembawa acara. Adapun susanan acara sebagai berikut: pertama pembukaan, kedua sambutan yang disampaikan oleh ketua program studi pendidikan bahasa Inggris, ketiga doa dengan harapan pengenalan aplikasi 
pembelajaran ini berjalan lancar. Dan yang terakhir adalah pelatihan pengenalan Edmodo sebagai alternatif media pembelajaran dalam kelas.

Sesi 2. pengenalan aplikasi dalam pembelajaran

Pada sesi ini tim pengabdi memberikan pengenalan terhadap beberapa aplikasi yang dapat dimanfaatkan dalam pembelajaran di kelas diantaranya adalah facebook, elearning unikama dan lain sebagainya.

\section{Pengenalan Edmodo}

Pengenalan Edmodo dilakukan dengan cara menjelaskan pengertian apa itu Edmodo, demonstrasi cara pembuatan akun, pengenalan fitur-fitur yang ada pada Edmodo, serta kegunaan dari masing-masing fitur yang tersedia. Adapun materi ynag disampaikan adalah:

Pengertian Edmodo.

Edmodo adalah situs jejaring sosial tempat berbagi data, event, jadwal lain sebagainya diperuntukkan bagi para guru dan murid. Edmodo adalah media sosial network mikroblogging yang aman bagi siswa dan guru. Edmodo didirikan oleh Nicolas Borg dan Jeff O'Hara, dua orang yang bekerja disekolah terpisah di daerah Chicago. Pada situs ini orang tua dapat berkomunikasi dengan guru/pengaja disekolah dan siswa didalam kelas edmodo.

\section{Fitur-fitur Edmodo}

Dalam aplikasi edmodo banyak sekali fitur yang dapat digunakan diantaranya adalah

A. Assignment. Assignment adalah tempat dosen mengupload materi dan mahasiswa mengerjakan tugas. Dosen dapat memberikan tugas pada fitur ini. Selain itu dosen dapat menentukan waktu yang diberikan kepada mahasiswa contohnya dosen memberikan tugas dan menutup jawaban pada jam tertentu maka jika ada mahasiswa yang terlambat mengumpulkan tugas tidak akan bisa mengumpulkan tugasnya karena otomatis secara sistem sudah tertutup.

B. File and Link: file and link berfungsi sebagai tempat mengapload materi. Disini dosen dapat mengunggah materi yang akan disampaikan dan juga dapat memberikan link laman tertentu untuk didownload oleh mahasiswa sehingga dapat memudahkan mahasiswa untuk membaca materi sebelum kelas dimulai.

C. Quiz: pada fitur ini dosen dpaat memberikan quiz kepada mahasiswa. Quiz dapat berupa pilihan ganda dimana hasil dari jawaban mahasiswa dapat langsung terkoreksi didalamnya karena pada fitur ini tersedia kolom jawaban yang benar sehingga jika bentuk soal pilihan ganda, dosen tidak perlu repot untuk mengoreksi jawaban mahasiswa. Bentuk soal yang lain pun dapat diberikan pada kolom ini. Tidak terbatas hanya pilihan ganda saja.

D. Polling:fitur ini berfungdi ntuk mengetahui survey dan hasil polling. Dalam fitur ini disediakan olom untuk membuat angket survei dan disediakan juga hasil dai polling yang diberikan. Hal ini memudahkan dosen dalam mengetahui hasil polling.

E. Gradebook: fitur ini digunakan untuk catatan nilai siswa. Nilai siswa dapat di tulis pada kolom ini dan menudahkan dosen untuk mengumpulkan nilai tanpa takut nilai mahasiswa akan tercecer dan terdokumentasi dengan baik.

F. Library: tempat menyimpan berbagai sumber pembelajaran. Dosen dapat menggunakan fitur in dan mahasiswa dapat melihat dan mengakses fitur ini untuk memperbanyak wawasan mereka.

G. Award badges. Fitur ini adalah standar pengukuran keberhasilan peserta didik 
dimanadosen dapat mengetahui seberapa besar perkembangan peserta didik.

\section{Sesi 3. Pembuatan akun}

Setelah sesi pengenalan Edmodo, sesi selanjutnya adalah demonstrasi pembuatan akun edmodo dan simulasi join grup kelas. Pada sesi ini semua mahasiswa mengakses edmodo.com dan membuat akun sesuai dengan panduan yang telah paparkan. Langkah-langkahnya yaitu pertama buka www.edmodo.com kemudian pilih gambar (as student) yang terkotak kuning untuk mahasiswa. Isi lode yang diberikan oleh tim pengabdi, klik sign up for free. kemudian peserta diminta untuk mengatur akun mereka dengan klik kolom pojok kanan atas "me" pilih setting. pada menu ini peserta dapat merubah tampilan profil mereka, menambahkan foto, mengubah informasi pribadi, nama, alamat email dan juga dapat merubah password sesuai dengan keinginan peserta.

Sesi 4. Simulasi join grup kelas.

Sesi dilanjutkan dengan join grup kelas. Disini tim memberikan kode grup dala hal ini tim telah membuat kelas vocabulary, peserta dapat bergabung dalam kelas ini. Dalam kegiatan ini semua peserta harus bertegur sapa dengan mengucap salam kepada sesama peserta yang lain.

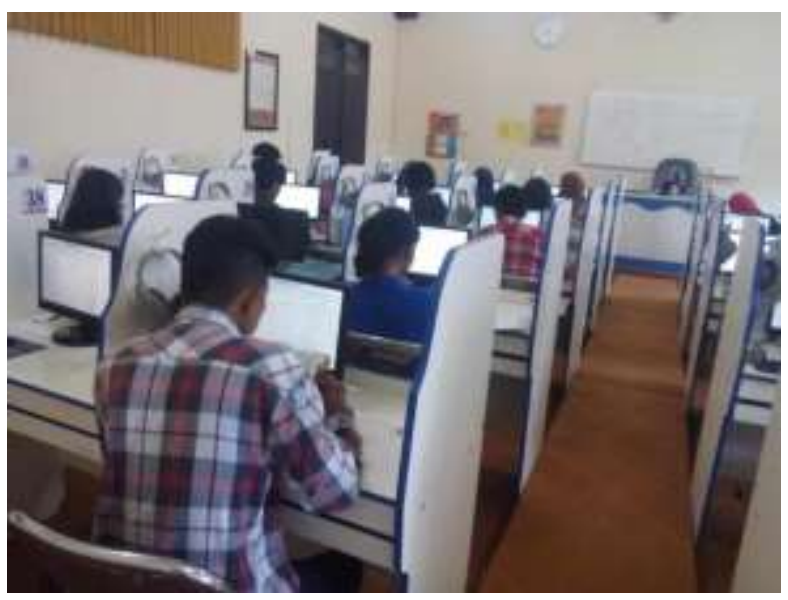

Gambar 1. Suasana pelatihan
Setelah bergabung dalam group peserta dapat membuka fitur-fitur yang ada dan mencoba mengerjakan simulasi tugas yang diberikan. Disini pemateri memberikan soal sederhana dan peserta menjawab pertanyaan melalui fitur yang telah disediakan.

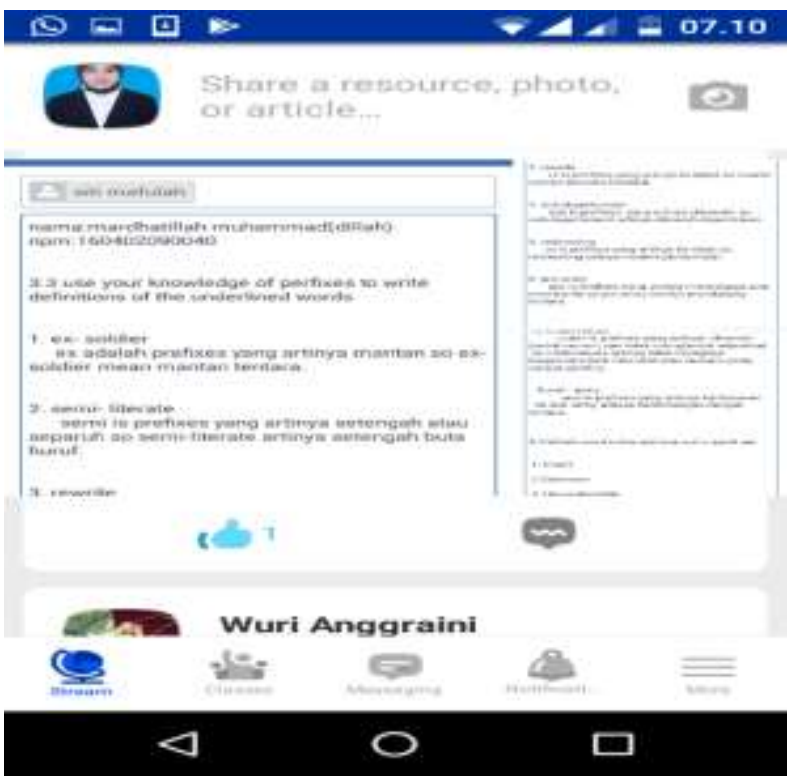

Gambar 2. Hasil simulasi join group

Sesi 5. Evaluasi

Setelah pelatihan dilaksanakan, tim pengabdian masyrakat mendapatkan hasil dengan melihat pada indikator keberhasilan pelatihan ini adalah:

1. Kemampuan peserta dalam memahami materi yang disampaikan oleh tim pengabdi tentang aplikasi edmodo sudah bagus, yakni peserta mengerti dan faham dengan materi yang disampaikan.

2. Mampu membuat akun sendiri dengan mengikuti langkah-langkah pembuatan akun yang telah disajikan pada sesi sebemnya.

3. Mampu mengerjakan soal trial bagi mahasiswa dengan menggunakan aplikasi Edmodo

Keberhasilan kegiatan ini jgua didapat dari peran aktif peseerta termasuk kehadiran dan keaktifan peserta melalui presensi kehadiran. Dari 25 mahasiswa yang menjadi peserta pelatihan semua (100\%) mengikuti kegiatan ini dengan baik. Kehadiran peserta pelatihan 
ini $100 \%$ dan ketepatan waktu hadir sebanyak $92 \%$ berarti 23 peserta datang tepat waktu dan hanya 2 peserta yang datang terlambat. Jika dilihat dari segi jadwal yang telah ditentukan serta ketepatan waktu pelaksanaan, kegiatan ini telah terlaksana dengan baik sekali, acara sesuai dengan rencana. Pada akhir acara peserta dan dosen membahas trial test yang diberikan dan melakukan penyebaran angket.

Dalam mengukur keberhasilan program ini, diakhir acar para peserta diminta mengisi lembar angket dan dapat disimpulkan bahwa program pengabdian ini mendapatkan tanggapan positif dari para peserta, dari hasil angket diketahui bahwa semua peserta berharap ada kontinuitas dari pelatihan semacam ini di lingkungan universitas kanjuruhan khususnya prodi pendidikan bahasa Inggris. Hal ini dapat dilihat dari jawaban pada angket yang diberikan. Hasil kuisionner dapat dilihat pada tabel 1 berikut ini.

Tabel 1. Hasil kuisioner

\begin{tabular}{|c|c|c|c|c|}
\hline $\mathrm{n}$ & Pertanyaan & \multicolumn{2}{|c|}{ Respon peserta } & alasan \\
\hline 1 & $\begin{array}{l}\text { Apakah } \\
\text { Apakah } \\
\text { pelatihan } \\
\text { semacam } \\
\text { ini harus } \\
\text { diadakan? }\end{array}$ & $\begin{array}{l}\mathrm{Ya} \\
100 \%\end{array}$ & $\begin{array}{l}\text { Tidak } \\
0 \%\end{array}$ & $\begin{array}{l}\text { Peserta } \\
\text { membutuhka } \\
\mathrm{n} \text { pelatihan } \\
\text { semacam ini } \\
\text { untuk } \\
\text { menunjang } \\
\text { keberhasilan } \\
\text { dikelas }\end{array}$ \\
\hline 2 & $\begin{array}{l}\text { Apakah } \\
\text { pelatihan ini } \\
\text { bermanfaat? }\end{array}$ & $\begin{array}{l}\mathrm{Ya} \\
100 \%\end{array}$ & $\begin{array}{l}\text { Tidak } \\
0 \%\end{array}$ & $\begin{array}{l}\text { Sangat } \\
\text { bermanfaaat } \\
\text { sekali karena } \\
\text { sangat } \\
\text { mudah } \\
\text { dimengerti } \\
\text { dan dapat } \\
\text { diaplikasikan } \\
\text { dengan baik. }\end{array}$ \\
\hline 3 & $\begin{array}{l}\text { Bagaimana } \\
\text { pendapat } \\
\text { anda } \\
\text { mengenai }\end{array}$ & $\begin{array}{l}\text { Sang } \\
\text { at } \\
\text { baik }\end{array}$ & Baik & $\begin{array}{l}\text { 1. sangat } \\
\text { bermanfaat } \\
\text { 2. Membuka }\end{array}$ \\
\hline
\end{tabular}

\begin{tabular}{|c|c|c|c|c|}
\hline & pelatihan ini & $85 \%$ & & $\begin{array}{l}\text { wawasan } \\
\text { 3. Memanfaa } \\
\text { tkan tenologi } \\
\text { untuk hal } \\
\text { yang baik }\end{array}$ \\
\hline 4 & $\begin{array}{l}\text { Cara } \\
\text { penyampaia } \\
\text { n materi } \\
\text { pada } \\
\text { pelatihan ini }\end{array}$ & $\begin{array}{l}\text { Sang } \\
\text { at } \\
\text { baik } \\
90 \%\end{array}$ & $\begin{array}{l}\text { Baik } \\
10 \%\end{array}$ & $\begin{array}{l}\text { Sangat baik } \\
\text { karena } \\
\text { langsung } \\
\text { praktik }\end{array}$ \\
\hline 5 & $\begin{array}{l}\text { Apakah } \\
\text { materi yang } \\
\text { disampaika } \\
\mathrm{n} \text { mudah } \\
\text { difahami? }\end{array}$ & $\begin{array}{l}\mathrm{Ya} \\
100 \%\end{array}$ & $\begin{array}{l}\text { Tidak } \\
0 \%\end{array}$ & Sangat jelas \\
\hline
\end{tabular}

Dari tabel diatas diketahui bahwa Jawaban dari pertanyaan nomor 1 "Apakah pelatihan semacam ini harus diadakan?" 100\% dari jumla peserta menjawab "ya". adapun bebrapa alasan disebutkan oleh peserta diantaranya adalah peserta membutuhkan pelatihan semacam ini untuk menunjang keberhasilan dikelas. "Apakah menurut anda pelatihan ini bermanfaat?" semua peserta menjawab “ ya" sedangkan alasan peserta menjawab pertanyaan ini diantaranya adalah Sangat bermanfaaat sekali karena sangat mudah dimengerti dan dapat diaplikasikan dengan baik.

Pada pertanyaan Bagaimana pendapat anda mengenai pelatihan ini juga mendapat respon yang sangat baik dari peserta $85 \%$ mengatakan pelatihan ini sangat baik dan sisanya $15 \%$ mengatakan baik saja. Dengan alasan pelatihan ini sangat bermanfaat, membuka wawasan serta dapat memanfaatkan tenologi untuk hal yang baik tidak hanya untuk bermain facebook dan youtube saja. Sedangkan untuk pertanyaan babgaiman cara penyampaian materi oleh tim mendapatkan respon yang bagus juga dengan $100 \%$ peserta menjawab sangat baik karena mudah difahami dan metode 
demonstrasi dan praktik adalah cara yang baik untuk mengingat sesuatu tidak hanya teori saja.

Dari uraian capaian yang telah didapat dapat diketahui bahwa program pelatihan yang disupport oleh lembaga penelitian dan pengabdian (LPPM) Universitas Kanjuruhan Malang dan prodi Pendidikan Bahasa Inggris berjalan sesuai dengan yang diharapkan dan berhasil sesuai dengan indikator capaian yang telah ditentukan.

\section{PENUTUP}

\section{Simpulan}

Pelatihan pengenalan EDMODO pada mahasiswa semester 2 prodi pendidikan Bahasa Inggris Universitas Kanjuruhan Malang terlaksana secara baik karena semua peserta mengikuti setiap sesi kegiatan dengan sangat antusias. Pelaksanaan kegiatan pengabdian ini berlangsung dengan baik, tertib dan sesuai dengan jadwal yang telah ditentukan. Pelaksanaan kegiatan ini dinyatakan berhasil mencapai tujuan yang telah di tentukan dengan tercapainya tolok ukur keberhasilan yang ditentukan oleh tim pelaksana. Para peserta mendapat pengetahuan baru serta meningkatkan wawasan tentang penggunaan Edmodo sebagai media yang menarik dan menyenangkan. diharapkan semua dosen prodi pendidikan bahasa Inggris dapat menggunakan aplikasi-aplikasi yang menunjang pembelajaran sehingga tidak monoton dan tidak diberikan secara tradisional saja.

Dengan pelatihan ini para peserta yang notabene adalah mahasiswa semester 2 merasa mendapatkan manfaat yang sangat besar karena nantinya aplikasi ini akan banyak digunakan oleh pengampu mata kuliah di kelas yang sesunggguhnya.

\section{Saran}

Dalam menunjang tercapainya target pembelajaran dalam kelas,penggunaan aplikasi seperti edmodo sangat diperlukan. Dengan penerapan aplikasi ini diharapkan nantinya mahasiwa juga lebih disiplin dalam mengerjakan tugas dan mengumpulkannya.

\section{Ucapan terimakasih}

Terimakasih kepada LPPM Universitas Kanjuruhan Malang yang telah membantu terlaksananya kegiatan pengabdian ini.

\section{E. DAFTAR PUSTAKA}

Basori. (2013). Pemanfaatan Social Learning Network "Edmodo" dalam Membantu

Perkuliahan Teori Bodi Otomotif di Prodi PTM JPTK FKIP UNS. JIPTEK. Vol VI, No. 2. (Online, diakses 20 Februari 2017).

Mafulah. S. (2017) Penggunaan Aplikasi Edmodo pada kelas vocabulary. Prosiding Konferensi Nasional Bahasa, sastra dan budaya 2017. Fakultas Bahasa dan Satra Universitas Kanjuruhan Malang.

www.edmodo.com 